\title{
Disaster, Donations, and Diaspora: The Response of the Japanese-Brazilian Community of São Paulo to the Triple Disaster of 2011
}

\section{Peter Bernardi}

The triple disaster or $3 / 11$, the devastating combination of earthquake, tsunami and the meltdown of reactors at the nuclear power plant Fukushima Daiichi that happened in Japan on March 11, 2011, was a globally reported catastrophe. The Japanese diasporic communities especially demonstrated their willingness to help, organize campaigns and send donations. While a commitment to restoring and relating to the homeland in some way confirms William Safran's (1991: 84) initial criteria for diasporas, the study of the Japanese diasporic communities' response to $3 / 11$ also offers insights into these communities and their status. This paper offers an analysis of the impact of 3/11 drawn from the reaction of the Japanese-Brazilian diaspora in São Paulo. Although initiatives to help Japan were started throughout Brazil, São Paulo hosts the largest and most influential nikkei community that organized the biggest campaigns. Furthermore, the article is my attempt to relate observed connections between disaster, donations and diaspora. I had originally scheduled fieldwork on Japanese immigration for March 2011, but after arriving in Brazil on March 12, reactions to the catastrophes of 3/11 were a constant topic in many encounters and overlapped my intended research on the nikkei community of São Paulo. Donations played an important role, and in this article I argue that help (especially financial) after 3/11 was not only about Japan but also the self-perception of the nikkei community in São Paulo. By donating and participating in the campaigns, Japanese-Brazilians were able to perform their identity as "Japanese" for the community itself, for the Brazilian society, and also for representatives of official Japan. To provide some background, a short overview over the nikkei community in São Paulo is followed by a historic focus on two previous initiatives for helping Japan. After reporting about the general response in Brazil to the catastrophes, the article then 
concentrates on São Paulo and presents how main actors reacted, how campaigns were perceived in the community, and which implications can be deduced.

\section{Japanese Diaspora in Brazil}

Brazil ranks first among the worldwide Japanese diasporas, counting more than 1.5 million Japanese and those with a Japanese heritage. Historically, Japanese immigrants were sent to Brazil in 1908 in order to work on coffee plantations and balance labor shortages after the abolishment of slavery in the late 19th century. Economic success came through individual and cooperative farming, along with a transition to urban areas and white-collar jobs. Today, many descendants of these settlers have gained considerable economic wealth and are seen as a "respected and highly educated immigrant group" (Brody 2002: 49). A disproportionally number of nikkei are not only students but also educators at schools and universities (Adachi 2004: 63). They have achieved political success as city councilmen, delegates and even ministers in different political administrations (Harada 2010). Among scholars, Japanese immigrants to Brazil and their descendants are therefore considered to be a "positive" or even highly integrated "model minority" (Adachi 2006: 12). In Brazilian society, the nikkei retain a positive (yet stereotypical) image and are often referred to as "Japanese" whose continued connection to Japan, their former homeland, is strongly assumed (Lesser 2007: 150). The nikkei's relationship with Japan has become more contentious since the 1990s, when the Japanese government changed immigration policies to attract foreign workers with Japanese ancestry. Especially Brazilian nikkei have gone to Japan to work in mainly blue-collar jobs and have settled there, even though they experience a stark contrast of their perception as undesirable foreigners. These workers-away-from-home or dekasegi now form the country's third largest minority, suffering from both discrimination and the effects of a declining economy (Reis 2002; Brody 2002).

In Brazil, a majority of nikkei live and work in the state of São Paulo and its capital, the city of São Paulo, where they have formed a visible community. The district of Liberdade is known as the "Oriental" or "Japanese district" because many 
Japanese immigrants once lived and established businesses here. ${ }^{1}$ Liberdade is also home to the main actors in the nikkei community of São Paulo, e. g.: its central entity, the association Sociedade Brasileira de Cultura Japonesa e de Assistência Social (burajiru nihon bunka fukushi kyōkai, abbreviated as "Bunkyo"), most prefectural associations (kenjinkai), and various other organizations. Apart from these official institutions, the daily Japanese-language newspapers São Paulo Shimbun and Nikkey Shimbun and their Portuguese counterpart, the weekly Jornal Nippak, a Buddhist temple, restaurants serving sushi, sashimi and ramen, Japanese convenience and specialty stores, and even banks attending customers in Japanese can be found in Liberdade.

With this concentration of formal and informal venues, Liberdade was a center of action and reaction in São Paulo after the catastrophe of March 2011. In the main plaza next to a bank styled after a medieval Japanese castle, gatherings were held and donations collected. Newspaper reports were posted in the offices of various kenjinkai where people from the prefectures met to communicate, making these offices hubs for gathering and distributing information as well as for coordinating help for Japan. Private initiatives appeared throughout the district and offered opportunities to voice feelings of grief and solidarity. One example often referred to in the media was the café Kōhī whose nikkei staff started a campaign not only to collect money but also to provide moral support. Guests were asked to leave messages or sign a twelve-meter long poster afterwards sent to Japan in cooperation with the dekasegi of Miyagi prefecture. Social media networks such as Orkut, the Brazilian equivalent to Facebook, were used to gather support and promote campaigns like Gambare Japão whose aim was to produce video messages in which Brazilians and Japanese-Brazilians alike expressed their wishes for a speedy recovery, ending with the phrase Gambare Japão. Other examples included a mass with the participation of Protestant, Catholic and Buddhist priests in the central auditorium of Bunkyo, fund-raising events such as dinners organized by Japanese-Brazilian chefs in São Paulo's city hall, concerts by the state's symphony orchestra, and art expositions. Labeling of these events ei-

1 Even though this name refers the visible presence of both Japanese, Chinese and Korean immigrants and their descendants, nowadays, the latter form a majority of the residents. 
ther gave mixed-language statements in Japanese and Portuguese, such as Gambare Japão and Nippon Ganbare, or implicitly called for help with titles such as SOS Japão or Everyone United for Japan. This multitude of campaigns and events show that the catastrophes of $3 / 11$ were very visible moments. Various actors organized the help for Japan and the various campaigns were not only reported in the media specifically used and produced by Japanese and Japanese-Brazilians but also gained attention in other newspapers and television programs. However, the fact that the Japanese diaspora of Brazil helped Japan after a natural disaster is by no means a new phenomenon. By linking the events of 2011 to other occasions, conclusions can be drawn about the relationship between Japan and Japanese descendants abroad.

\section{Helping Japan}

The relationship to Japan, especially in times of crisis, was always a topic among Brazilian nikkei. One of the earliest efforts took place in 1947. During the Second World War, the Brazilian state sided with the Allied Powers and especially discriminated against Japanese - as well as German and Italian - immigrants as a suspected fifth column. After Japan's surrender, the Japanese community in Brazil was sharply divided between two groups. Those who believed that Japan had actually won the war (kachigumi) defended their view, sometimes with organized terrorist attacks, against the minority that accepted the defeat (makegumi) (Adachi 2004: 59). Only after the Brazilian state and Japan finally intervened in the early 1950 s was this situation resolved - but at the cost of a confused community. In 1947, a group of Japanese immigrants in São Paulo founded the Committee to Help the Victims of the War in Japan (Comitê de Socorro ás Vítimas da Guerra no Japão) and organized donations to post-war Japan. The committee acted with the support of the Brazilian Red Cross and worked together with the American occupiers, sending goods and CARE packages worth about $\$ 15,000$ to Japan until July 1950 (Handa 1987: 743). Apart from providing help to the immigrants' homeland, the committee was also considered to be an institution that might help to unite the divided immigrants through a common cause. But the makegumi group's cooperation with the Americans, a former enemy, intensi- 
fied the conflict between kachigumi and makegumi groups. Because only a small number of the immigrants participated and the project met massive resistance from the kachigumi groups, the campaign failed in this larger goal of uniting the immigrants (Beltrão 2008: 257).

The last event that involved Brazilian nikkei in efforts to help Japan was the earthquake of 1995 that devastated Kōbe city and southern parts of Hyōgo prefecture. It claimed about six thousand lives, the majority of them inhabitants of Kōbe. With an estimated five thousand Brazilian nikkei living in Hyōgo prefecture and about one thousand in Kobe itself, the community in Brazil tried desperately to contact friends or family in Japan (Takezawa 2002: 313). Uncertainty continued with rarely-working telephone lines and delayed official information until the Japanese government confirmed the first Brazilian nikkei victim. Of 173 foreign victims counted, eight were Brazilian nikkei (Takezawa 2002: 315). The nikkei media in Brazil widely reported their fates and also the stories of those who were injured or had lost their belongings or housing (São Paulo Shimbun 1995a). These very personal links to the disaster directly involved and affected the community. Various actors as the kenjinkai of Hyogo province or Bunkyo met, and although they started individual campaigns for material and moral support, no organization assumed responsibility for a joint campaign (São Paulo Shimbun 1995b). Financial donations were individually collected and likewise distributed; the Hyōgo dekasegi transferred its donations directly to the government of Hyōgo prefecture itself (São Paulo Shimbun 1995C: 1). This individualization of donations was also present in the campaign of Banespa Bank, one of the biggest Brazilian banks with branches in Japan. Banespa started the S.O.S. Japão campaign, the donations of which were to be used to support Brazilian NGOs that helped especially Brazilian dekasegi and Brazilian victims of the earthquake (São Paulo Shimbun 1995d: 4). In total, Brazilian nikkei contributions to the affected prefectures were estimated at $\$ 820$,000 (Takazawa 2002: 316).

We can consider both reactions in 1947 and 1995 to be a form of solidarity in which the group that received help was clearly identified as one's own. Helping in 1947 meant helping a Japan that the immigrants felt an allegiance to and had 
until recently called their homeland. In 1995, this relationship had changed and help also targeted various compatriots from Brazil and those who were, in turn, helping them. The example of Kobe displays a more heterogeneous direction of help. The catastrophes of 3/11 show different perspectives on help from a diasporic community.

\section{Reactions to 3/11 in Brazil}

The Japanese government requested and received international assistance after the catastrophes of 3/11. Countries such as Australia, the United Kingdom and South Korea dispatched earthquake rescue teams. Others sent relief goods, food, blankets, and emergency lamps, with the majority of goods coming from China and the United States of America (Okada et al. 2011: 39). The Japanese government of Prime Minister Naoto Kan also received various offers of further help and decided that all financial help after the catastrophe was to be given to the Japanese Red Cross. Worldwide, more than one billon dollars were collected by April 3 (Okada et al. 2011: 39). Fund-raising was therefore a strong focus in many diasporic communities.

On a national level in Brazil, President Dilma Rousseff immediately sent an official note to Prime Minister Kan. While President Rousseff expressed her condolences and Brazil's readiness to participate in international efforts to help Japan, she also specifically mentioned the special connection to the Brazilian nationals living in Japan (Blog do Planalto 2011). As one of the first officials, Brazilian Minister of External Relations Antonio Patriota called his Japanese colleague Takeaki Matsumoto to express his condolences and Brazil's solidarity. The Brazilian government followed with a donation of $\$ 500$,000, which it transferred to the Japanese Red Cross, conforming to the wishes of the Japanese government (São Paulo Shimbun 2011a).

Reactions among the nikkei community in São Paulo can be divided into two phases: a shorter state of shock and confusion followed by an active and longer phase of organizing concrete help. After Brazilian television broadcasted the pictures of earthquake and tsunami, many tried to contact friends or family members working in Japan. As one of my contacts in the field mentioned, the Brazil- 
ian media in these first days visited many associations of the community and reported emotional stories of missing relatives and their fates. But these stories soon diminished because in stark contrast to the catastrophe of Kobe in 1995, no Brazilian nikkei lost his or her life during $3 / 11 .^{2}$

A quote from a representative of a nikkei NGO in the weekly Jornal Nippak sums up the second phase in a nutshell: "What the Japanese need now is moral support and financial help" (Shiguti 2011a). ${ }^{3}$ Immediately after the earthquake, leaders of influential Japanese-Brazilian associations met in Liberdade to coordinate a joint response. The aforementioned Bunkyo, the federation of the prefectural associations (kenren), the philanthropical Beneficência Nipo-Brasileira de São Paulo (Enkyo), the cultural association Aliança Cultural Brasil-Japão, and the Chamber of Japanese Commerce and Industry in Brazil decided to launch a combined campaign to collect donations; the campaign was formally named the Campaign to Collect for the Victims of the Earthquake in Japan. The organizers created four different bank accounts for donations. In the beginning, they did not decide exactly who should receive these donations, but on March 22, the committee announced that all donations would be transferred to the Japanese Red Cross, adding that city- and state-wide responses were promising (Abe-Oi 2011c). The campaign raised more than 3.2 million Reais, about one million dollars, in the initial ten weeks (Abe-Oi 2011e). In addition to participation from actors in São Paulo city, many Japanese associations in the interior of São Paulo state submitted substantial donations ranging from about $\$ 1,000$ to $\$ 5,000$. The campaign also counted small donations from unidentified donors, supposedly Brazilians without Japanese ancestry. This was a huge effort for the community and its members. Bunkyo was the organization that made this process public by presenting donors and their reasons to participate on their homepage. The organizing committee also communicated the amount of donations in weekly press conferences, although they had agreed not to communicate the amount of each one's collection.

2 Interestingly enough, media in Brazil concentrated more on the dimensions of the natural disasters of earthquake and tsunami while in contrast, German media reporting put its main focus on the efforts to control the nuclear power plant.

3 All translations of Portuguese sources are from the author. 
The keyword in this campaign was "solidarity" (solidariedade), but its interpretations were ambiguous. As an idea, solidarity in Brazil has not only been linked to Christian and socialist ideals but also was fixed in 1988 as a fundamental principle of Brazil's constitution (Rosso 2007: 206). Definitions of the word connect it to a humanitarian idea of helping "those unprotected, those who suffer, the unjust treated" with an "intent to comfort, console and offer help" yet limits it to a specific group that shares "common attitudes and sentiments [...] to form a strong unit" (Houaiss 2001: 2602). In the early immigrant nikkei community, solidarity was also strong principle for mutual help (Handa 1987: 771).

This complex interpretation manifested in the "messages of solidarity" released by the organizing committee to different audiences: to the Japanese government of Prime Minister Kan and to the nikkei in Japan and Brazil. All messages published on Bunkyo's homepage drew heavily on the term "solidarity" and expressed the intent to help, but their focuses were different. The message in Portuguese and Japanese addressed Prime Minister Kan "in the name of the Japanese-Brazilian community" and established the status of the signees as representatives of the community who acknowledge and praise political initiatives of Kan's government. The organizing committee announced that the community "was studying possible ways of collaborating with the efforts, using all of its modest capacity" (Abe Oi 2011b) but gave no further details although bank accounts for receiving donations were already set up. Solidarity in this context meant positioning oneself in a political context. The messages to Brazilian nikkei in Japan and Brazil were more practical. They asked them to remain calm, inform their relatives in Brazil when possible, and also announced the start of the campaign "with the aim to find a form to show our solidarity to Japan" (Abe Oi 2011a). These also invoked a sense of a larger (Japanese) community, assuring that "we want to express profound solidarity because we share the great pain that overwhelms the whole Japanese nation" (Abe Oi 2011a). These communiqués once again established the organizers as responsible representatives of the JapaneseBrazilian community, whether in Japan or Brazil. But by focusing on solidarity, the organizers included the nikkei of Brazil in a concept of Japanese community 
that surpassed national borders. This idea of a solidarity among Japanese is also apparent in the way donations were given and received.

A donor could theoretically just transfer the money to the bank accounts created for this occasion. This procedure would be much easier, more transparent and even safer for all parties concerned. However, many donations from the nikkei community were made in person, and especially those coming from Japanese associations, clubs and circles (nihonjinkai) followed a very similar pattern; when those donors came to the Bunkyo building in Liberdade to deliver their contribution, they were received by Bunkyo's president, Kihatiro Kita, or a colleague from the administration. As the donor formally delivered the check, the Bunkyo staff took pictures and posted a report online afterwards. The donors in this situation presented themselves as participants and expressed their (expected) solidarity with Japan, further confirmed by pictures, reports and donation receipts. Donating money became a performative act in which members of this group confirmed their right to belong. Solidarity in this sense was shown and proven.

\section{Reacting to 3/11: Solidarity with the Japanese}

The donors to the general campaign to help Japan ranged from individuals and Japanese associations from the interior of São Paulo state to sport clubs, cultural institutions and nikkei-owned companies. The Bunkyo homepage functioned as an official forum that presented these contributors and their reasons to participate. Especially among smaller contributors, help for Japan was explained as help to a group they considered themselves to be a part of, the group of "Japanese". This idea of solidarity expands from a humanitarian idea to a very specific feeling of solidarity within a group. The opposite of Gayatri Spivak's concept of "othering" (Spivak 1985), this process might be called "ouring". Participating in the campaign meant demonstrating one's own link to Japan and identifying as Japanese among the community in Brazil. 
The association Shimbokukai e Fujinkai de Vila Santa Izabel donated the relatively small sum of about $\$ 1,500 .{ }^{4}$ In the interview on the Bunkyo homepage, the three female representatives of the Fujinkai framed their participation as a natural act: "We are very grateful to Japan, and this is the moment to return the favor to the country our ancestors came from and where our children now live" (Abe-Oi 2011d). References to family ties run through the whole interview: to help Japan meant to help "our Japanese brothers and sisters". The speakers define themselves as members of this Japanese family that includes Brazilian nikkei in Japan (Abe-Oi 2011d). In contrast to larger contributions that resulted from refined campaigning, the example of the Fujinkai also shows participation on a smaller scale. The Fujinkai is located in southern São Paulo and operates in a modest neighborhood with few families of Japanese ancestry. Its members are mostly elderly Nisei and the association functions as a contact point for their informal activities, such as karaoke, Japanese language classes, rajio taisō (radio gymnastics) and bingo games. Aside from the actual amount of the contribution, there also exists an emotional meaning. The money came not from a specific campaign but from the personal savings account of the Fujinkai. The contribution was thus understood as a sort of familial legacy. The members of Fujinkai explained that its money should be better used to help Japan since their "association will not survive for much longer" because of their own ages and missing younger members (Abe-Oi 2011d).

In a way, the example of the Fujinkai symbolizes both status quo and actual problems among São Paulo's nikkei society. Although a large number of associations, groups and clubs exist, they experience a kind of recruitment problem connected to a changed relationship to Japan. The contribution of the Fujinkai also shows that participating meant including oneself and one's organization within a Japanese community, be it transnational with Japan or regional in São Paulo. The catastrophes of 3/11 strengthened the relations between actors who worked together for a common aim: helping Japan by providing donations. Their success lies, therefore, less in the result of this collection and the sum of one million

4 To facilitate reading, this association for informal social gathering (shinbokukai) and its women's association (fujinkai) will be abbreviated to "Fujinkai". 
dollars but more in the process of achieving it. Even though actors had organized campaigns for other objectives in Brazil, like the flooding in Rio de Janeiro, the "affected home" Japan added to the equation. Participating and donating meant demonstrating solidarity while identifying as Japanese and being recognized as such by others. The expectation that Japanese were obligated to participate also meant that those who were not present had denied their contribution, meaning they would not identify themselves as Japanese. The nikkei community constructed their need to show solidarity not only from a humanitarian perspective but also as an obligation owed to one's own group or family, which further strengthened the process of "ouring" among the self-imposed category of "Japanese".

"Ouring" even extended to contributions from Brazilians without Japanese ancestry. Their favorable image of "Japanese" and therefore motivation to help was developed from the positive stereotypes about the nikkei in Brazil and especially in São Paulo. They directly linked the Japanese in Japan to the nikkei in Brazil, as a contact recalled the reasoning of one donor in particular:

There was a woman, who came here right after the events of our campaign started and who we perceived to be a simple domestic maid [...] and she gave twenty Reais [about $\$ 10$ ]. She said: "No, I insist. This is all I've got, all that I have left at this moment. But I insist. The Japanese are very correct, they are very hard workers, they deserve that we help them" [...]

"So, you are familiar with Japan?"

"No, but I know you, and you [plural] are the best."

Helpful as it may have been in the campaign, this form of performative and associated solidarity also posed a problem. The categorization of Japanese through donations became an open field that could and would be contested.

\section{Reacting to 3/11: Friction and Conflict}

The reaction of the nikkei community seems clear and well structured; existing institutions and their representatives assumed responsibility, organized a joint campaign, while individuals and associations contributed with financial donations that were distributed. Help was therefore provided to Japan. But who was allowed to organize campaigns and represent the community? While the variety 
of campaigns was remarkable, this also led to problems of differentiating between them. Even those five organizations coordinating the campaign together used different names: Campaign to Collect for the Victims, Nippon Gambare, and SOS Japão. Among nikkei and non-nikkei contributors, there was apparently not only a great desire to help but also a feeling of uncertainty regarding who was authorized to collect the donations. All official documents and press releases warned that no one was allowed to gather donations in person, but as one incident proved, there were those who used ethnicity and this solidarity as a cover for criminal gains.

Rosário Kazuhaki Yamamoto is a known Japanese-Brazilian con artist who already had posed as a distant relative of Japan's Imperial family to obtain money during the commemoration of Japanese immigration to Brazil in 2008. In 2011, he re-appeared in Liberdade wearing a doctor's coat and pretended to be a representative of an association participating in the campaign. He successfully lured businessmen into sponsoring a fictional fund-raising bazaar (São Paulo Shimbun 2011 b). As one victim remarked afterwards, in addition to his doctor's coat, Yamamoto's look as a Japanese-Brazilian also made him credible, even more so because he spoke both Japanese and Portuguese. This attempt to capitalize on the catastrophe was not just seen as an act of a criminal but taken as an "attack on the community" (São Paulo Shimbun 2011b). This reaction shows the fear that members of the community themselves would besmirch the nationwide campaign. Yamamoto's example illustrates the warring question of who was allowed to act and by extension speak for and represent the community. Friction appeared within the community, and in tracing these moments a different perspective of the meaning of $3 / 11$ can be drawn. Two examples of friction among the community illustrate the variety of meanings.

The biggest contributor to the campaign was the religious sect Seichō-no-ie. On April 4, its delegation visited the Bunkyo building and delivered a check of about $\$ 250,000$. The presentation of the donation to the presidents of Bunkyo, Enkyo, and Kenren followed the routine of other donations: words of gratitude were spoken and pictures of those involved taken. However, the circumstances of this contribution were very different. Published pictures show a highly for- 
malized setting resembling a press conference with opposing groups and tables no other contributors were met like this. Most often, a member of the executive board of Bunkyo received donors, whereas this time, three presidents of the organizing committee were present. Seichō-no-ie even brought a journalist from their own journal, thus partly taking control of the presentation afterwards when they published an account of the meeting on their own websites, adding their own pictures and a link to an article about their donation (Seichō-no-ie 2011). This case suggests a different reason for participating in the campaign. It can be concluded that donating in Seichō-no-ie's case meant not only showing one's religious beliefs and solidarity with the Japanese but also presenting oneself as an influential actor. While Seichō-no-ie is one of the Japanese "New Religions" (shinshūkyō) which have gathered a large following in Brazil, its influence on society is also seen critically (Usarski-Shoji 2008: 3). Bunkyo and other institutions are normally cautious towards religious organizations, but in this case, they had to accept the donation and in doing so, also accept Seichō-no-ie as an important part of campaign and community. Showing solidarity in this case meant publicity and a marketing possibility because all news media of the community reported the contribution. In contrast to this, the largest individual donor who contributed about $\$ 100,000$ chose not to identify himself (Abe-Oi 2011e). Seichō-no-ie's use and distribution of their own material through their own forms of media also demonstrates the focus on publicity because the published report and pictures concentrate on the gratitude shown by the organizers as representatives of the nikkei community.

In contrast to Seichō-no-ie's example of pursuing one's own agenda through participating, the example of Liberdade's shop owners association ACAL (Associação Cultural e Assistencial da Liberdade) illustrates the effects of refusal. If "being Japanese" meant collecting donations, then it became an impetus for any nikkei organization. Those who refused to contribute in any way - not only financially - to the campaign came under pressure. Shortly after the catastrophes, ACAL's executive board send out a communiqué to its members and associates. It labeled any initiatives to collect donations "hasty", arguing that Japan had "enough financial and human resources to normalize the situation" (Shiguti 
2011b: 4). The message also stated that participating in any campaign would be neither necessary nor wanted by the Japanese government. This drew heavy criticism from the public, the media and ACALs own associates (Shiguti 2011b: 4). Participating was expected, and not surprisingly, some days later, ACAL organized its own one-day campaign in collaboration with the Red Cross (albeit the Brazilian charter). ${ }^{5}$

\section{The Meaning of $3 / 11$ for the Japanese Diaspora in Brazil}

The Japanese-Brazilian community in São Paulo was a driving force behind efforts to aid Japan after $3 / 11$. It started various initiatives that provided moral and financial support. Nevertheless, to evaluate these contributions is a difficult and contested question. Organizers such as Bunkyo president Kita considered the results a success that "surpassed [their] expectations" (Abe-Oi 2011e), but others criticized both the campaigns and the motives to participate. Rodrigo Meikaru, editor of the journal Mundo OK, described it as "one event here, one event there, but nothing big" and declared that "the Japanese-Brazilian community [...] did not show great efforts to help Japan" (Meikaru 2011: 5). The journalist Nelson Fukai saw a very different picture of "solidarity" when he compared reactions in Japan and Brazil, addressing that participating in Brazil was mainly used for publicity: "Here in Brazil, mainly in the nikkei [sic!] community..., what a shame! Solidarity yes, for those who want to present themselves!" (Fukai 2011). Compared to the sum collected on a global scale, the sum of about one million dollars (about three million Brazilian Reais) from private donations ought to be considered symbolic, as a member of the Bunkyo staff confirmed: "We know that three million [Reais] were not sufficient at all but [meant to] [...] demonstrate a feeling of solidarity" (2011, 021-230). ${ }^{6}$ It can be argued that the process of collecting and its impact on the community was more important than the donated sum itself.

5 This short-term solution was criticized because the Brazilian charter of the Red Cross charged ten percent of the collected money as an administration fee. Since late 2011 the Brazilian charter has also been under suspicion for possible embezzlement of funds with the campaign for the victims of $3 / 11$ being among those investigated (Leitão, 2012).

6 a gente sabe que tres milhões não deu para nada, mas [...] demonstrar um sentimento, ne de soliedaridade (2011, 021-023). 
On the one hand, the main campaign cemented the claim of established institutions such as Bunkyō and the kenjinkai to represent the nikkei community and made them more visible. Participating meant constructing one's identity as being Japanese. The public campaigning for donations and its "ouring" as an expression of ethnic solidarity also meant mobilizing broader audiences, both non-nikkei and nikkei, which resulted in the "strengthening [not only] of local relations but also of relations inside the community as well as with local [Brazilian] society", as a Bunkyō contact stated. ${ }^{7}$ Participating in the campaign also had an impact on power relationships, either gaining (positive) publicity or sanctions from a refusal. While the act of donating was publicly acknowledged (and partly self-presented), the amount of money could also serve as a confirmation of one's own relevance and power in contrast to others. It may be concluded that the catastrophes of 3/11 were a tragic event in which the Brazilian nikkei diaspora experienced and constructed its connection to Japan: on the one hand, internally through its own efforts with campaigns, and on the other hand, externally through the attention of non-nikkei society, which supported and expected this symbolic show of solidarity with Japan.

This leads to a general question of how diasporic communities respond to disasters in their (ethnic) homeland. As shown in this article, disasters can be seen as experiences of a connection to one's homeland, tragically conforming to Safran's idea of relating and restoring. Regardless of geographic locations, modern media supplies pictures and other impressions that trigger reactions. Solidarity and its various forms of expressions, varying from financial donations to public demonstrations, become an externally and internally expected reaction. Identity is constructed from the periphery through internal "ouring" but may be confirmed by external opinions.

The catastrophes of $3 / 11$ had global repercussions on the Japanese diaspora. It may be argued that they became part of the diaspora's history and in this sense ought to be remembered. In March 2012, two nikkei organizations supported by Mitsubishi and the city of São Paulo began to plan a memorial. Twenty thousand

7 "um fortalecimento das relações locais mas também dessas relações dentro da comunidade como também da sociedade local" (2011, 002). 
tree seedlings, representing the number of assumed victims, are to be planted in a park in the Eastern district of São Paulo (Jornal Nippak 2012). So far, donations are still being collected, but naming this memorial the "Kizuna Park Brazil Japan" (Bosque Kizuná Brasil Japão) shows a close orientation toward the discourse of Japanese politics and of "bonds between people" (kizuna) in the reactions to the catastrophes in Japan (Tagsold, 2012). It remains to be seen how the catastrophes of $3 / 11$ will be seen and remembered not only in São Paulo but also in other diasporic nikkei communities.

\section{Literature}

Abe OI, Célia. (2011a): "Manifesto de Soliedaridade ao Japão da comunidade nipobrasileira" [Manifest of solidarity with Japan from the Japanese-Brazilian community]; http://www.bunkyo.bunkyonet.org.br/index.php" option = comcontent\&view = arti cle\&id $=1033 \% 3$ Amanifesto-de-solidariedade-do-japao-da-comunidade-nipo-brasileira\&c atid $=84 \% 3$ Aterremoto- 2011 \&ltemid $=122$ \&lang $=$ br. (accessed October 12 2014)

Abe Oı, Célia. (2011b): "Do Brasil, a Mensagem de Solidariedade aos Japoneses" [A Message of Solidarity to the Japanese from Brazil]; http://www.bunkyo.bunkyonet.org.br/in dex. php" option = comcontent\&view $=$ article\&id $=1035 \% 3$ Ado-brasil-a-mensagem-de-so lidariedade-aos-japoneses $\&$ catid $=84 \% 3$ Aterremoto-2011 \&ltemid $=122 \&$ lang $=$ br. $\quad$ (accessed October 14, 2014)

ABE OI, Célia. (2011c): "Cruz Vermelha do Japão receberá a arrecadação da campanha em prol das vítimas do terremoto" [Red Cross of Japan Will Receive the Collection of the Campaign on Behalf of the Victims of the Earthquake]; http://www.bunkyo.bun kyonet.org.br/index. php" option $=$ comcontent\&view $=$ article\&id $=1047 \% 3$ Acruz-vermel ha-do-japao-recebera-a-arrecadacao-da-campanha-em-prol-das-vitimas\&catid $=84 \% 3 \mathrm{Ate}$ rremoto-2011 \&ltemid = 122\&lang = br. (accessed October 14, 2014)

Abe OI, Célia. (2011d): "Vila Santa Izabel na Campanha de Arrecadação às Vítimas do Terremoto no Japão" [Vila Santa Izabel in the Campaign to Collect for the Victims in Japan]; http://www.bunkyo.bunkyonet.org.br/index.php" option = comcontent\&view =ar ticle\&id = 1101\%3Avila-santa-izabel-na-campanha-de-arrecadacao-as-vitimas-do-terrem oto-no-japao\&catid $=84 \% 3$ Aterremoto- 2011 \&ltemid $=122 \&$ lang $=$ br. $\quad$ (accessed October 15, 2014)

Aвe-Oı, Célia. (2011e): "Resultado final da Campanha em prol das vítimas do terremoto no Japão" [Final Result of the Campaign for the Victims of the Earthquale in Japan]; http://www.kenren.org.br/noticias/not\%C3\%ADcias-relacionadas/item/67-result 
ado-final-da-campanha-em-prol-das- $\mathrm{v} \% \mathrm{C} 3 \%$ ADtimas-do-terremoto-no-japão. (accessed October 29, 2014)

ADACHI, Nobuko. 2004. "Japonês: A Marker of Social Class or a Key Term in the Discourse of Race”. In: Latin American Perspectives, 31 (3): pp. 48-76.

ADACHI, Nobuko. 2006. “Theorizing Japanese Diaspora” In: Adachi, Nobuko. (ed.): Japanese Diasporas: Unsung Pasts, Conflicting Presents and Uncertain Futures. New York: Routledge, pp. 1-22.

Beltrão, Kaizō et al. 2008. "Haíne: Raízes [Roots].” Curitiba: Associação Brasileira de Dekasseguis.

Blog do Planalto. 2011. "Presidenta Dilma coloca o Brasil à disposição do governo japonês após terremoto" [President Dilma Places Brazil at Disposal of the Japanese Government after Earthquake]; http://blog.planalto.gov.br/presidenta-dilma-co loca-o-brasil-a-disposicao-do-governo-japones-apos-terremoto. (accessed July 26, 2014)

Brody, Betsy Teresa. 2002. Immigration, Ethnicity, and Globalization in Japan. London: Routledge.

FuKaI, Nelson. 2011. "O marketing de disgraça" [Shameful Marketing]. In: Mundo OK: 4.

Handa, Tomoo. 1987. O imigrante Japonês - História de sua vida no Brasil [The Japanese Immigrant - History of His Life in Brazil]. São Paulo: Centro de Estudos Nipo-Brasileiros.

Harada, Kiyoshi. 2010. "A Presença do Nikkei no Cenário Nacional" [Presence of Nikkeis on the National Scenario]. In: Various. Centenário: Contribuição da Imigração Japonesa para o Brasil Moderno e Multicultural [Centenário: Contributions of the Japanese Immigration to Brasil Modern and Multicultural]. São Paulo: Paulo's Comunicação e Artes Gráficas, pp. 223-235.

Houaiss, Antōnio and; Villar, Mauro de Salles. 2001. Dicionário Houaiss da Língua Portuguesa. Rio de Janeiro: Objetiva.

Jornal NipPaK. 2012. "Convite ABIJA e OISCA - Plantio de árvores dia 17/03/2012" [Invitation ABIJA and OISCA - Planting of Trees at 17/03/2012]; http://www.port alnikkei.com.br/convite-abija-e-oisca-plantio-de-arvores-dia-17032012/. (accessed August 19, 2014)

LeItÃo, Leslie. 2012. "S.O.S. Cruz Vermelha" [S.O.S. Red Cross], VEJA 2281, 8.8.2012, pp. $120-123$.

Lesser, Jeffrey. 2007. A Discontented Diaspora: Japanese Brazilians and the Meanings of Ethnic Militancy, 1960-1980. Durham: Duke University Press.

Meikaru, Rodrigo. 2011. "Senso de solidaridade" [A Sense of Solidarity]. In: Mundo OK: 4. 
OKADA, Norio et al. 2011. "The 2011 Eastern Japan Great Earthquake Disaster: Overview and Comments". In: International Journal of Disaster Risk Science, 2 (1): pp. 34-42.

ReIs, Maria Edileuza Fontanele. 2002. Brasileiros no Japao: o elo humano das relacoes bilaterais [Brazilians in Japan: The Human Tie of the Bilateral Relationship]. São Paulo: Kaleidus-Primus. 2nd revised edition.

Rosso, Paulo Sergio. 2007. "Solidariedade e direitos fundamentais na Constituição Brasileira de 1988" [Solidarity and Fundamental Rights in the Brazilian Constitution of 1988]. In: Revista Eletrōnica do Centro de Estudos Jurídicos/CEJUR, 1 (2): pp. 201-222.

São Paulo Shimbun. 1995a. "Morte e sofrimento no rastro do terremoto" [Death and Suffering in the Wake of the Earthquake]. 18.1.1995.

São Paulo Shimbun. 1995b. "A soliedaridade da comunidade" [The solidarity of the Community]. 20.1.1995.

São Paulo Shimbun. 1995c. "Brasileiros estão sendo atendidos em Osaka" [Brazilians Are Treated in Osaka]. 2.2.1995.

São Paulo Shimbun. 1995d. 04.02.1995.

SÃo Paulo Shimbun. 2011a. "Brasil doa US $\$ 500$ mil e Japão agradece” [Brazil Donates 500.00o US\$ and Japan Gives Thanks]. 22 March; http://www.saopauloshimbun.com/ sitebr.php/conteudo/show/id/1079/menu/31/cat/112. (accessed June 2, 2014)

São Paulo Shimbun. 2011b. "Estelionatário volta a atacar a comunidade usando o nome do São Paulo Shimbun" [Trickster Returns to Attack the Community Using the Name of SãO Paulo Shimbun]. August 29; http://www.saopauloshimbun.com/sitebr.php/con teudo/show/id/1450/menu/33/cat/115. (accessed October 15, 2014)

SAfran, William. 1991. "Diasporas in Modern Societies: Myths of Homeland and Return”. In: Diaspora, 1 (1): pp. 83-99.

SEICHŌ-NO-IE. 2011. "SEICHO-NO-IE DO BRASIL faz entrega de doação que será encaminhada às vítimas do terremoto e tsunami do Japão" [Seichō-No-Ie Delivers the Donation Which Will Be Sent to Victims of the Earthquake and Tsunami in Japan]; http://www.sni.org.br/SEICHO-NO-IE-DO-BRASIL-faz-entrega-de-doacao-que-sera-enca minhada-as-vitimas-do-terremoto-e-tsunami-do-Japao.asp. (accessed August 29, 2014)

Shiguti, Aldo. 2011a. "O pânico maior é por parte dos estrangeiros, diz Hashimoto" [The Bigger Panic Comes from the Foreigners, Says Hashimoto]. In: Jornal Nippak, 17-23.03.2011.

Shiguti, Aldo. 2011b. "Acal se retrata por informe 'equivocado' sobre campanhas" [Acal Recants "Mistaken" Information about Campaigns]. In: Jornal Nippak, 31.3.06.04.2011.

SPIVAK, Gayatari. 1985. “The Rani of Simur”. In: Barker, Francis et al (eds.): Europe and its Others. Colchester: University of Sussex. 
TAGsold, Christian. 2012. "Kizuna: Das Schriftzeichen des Jahres 2011 als Antwort auf das gefühlte Auseinanderbrechen der Gesellschaft" [Kizuna: The Kanji of the Year 2011 as an Answer to the Angst That Japanese Society Will Soon Break Apart]. In: Japan Jahrbuch: pp. 309-328.

TAkezawa, Yasuko. 2002. "Nikkeijin and Multicultural Coexistence in Japan." In: Hirabayashi, Lane Ryo: New Worlds, New Lives: Globalization and People of Japanese Descent in the Americas and from Latin America in Japan, Stanford: Stanford University Press, pp. 310-330.

UsARski, Frank; and ShojI, Raphael. 2008. "Japanese Religions in Brazil”. In: Japanese Journal of Religious Studies, 35 (1): pp. 1-12. 